\title{
Detection of human papillomavirus DNA in colorectal carcinomas by polymerase chain reaction
}

\author{
J Y Cheng, L F Sheu, C L Meng, W H Lee, J C Lin
}

\begin{abstract}
Human papillomaviruses (HPVs) are associated with a number of benign and malignant neoplasms. To substantiate the relationship between HPV DNA and colorectal carcinomas, 70 carcinomas and 37 adenomas were analysed in this study. Specific types of HPV DNA in colorectal tumours were detected by polymerase chain reaction (PCR) and Southern blot hybridisation. HPV DNA was detected in 11 of $37(29.7 \%)$ adenomas and in $52.9 \% 37$ of $70(52.9 \%)$ of carcinomas. The expression of HPV DNA in adenomas and carcinomas, especially that of HPV 16 in HPV positive cases ( 4 of $11 v 26$ of 37), was significantly different $(p<0 \cdot 05)$. There was no correlation, however, between HPV and the location, differentiation, stage, or survival of malignant neoplasms. These data suggest that HPV DNA, especially type 16, is associated with colorectal carcinogenesis.

(Gut 1995; 37: 87-90)
\end{abstract}

Keywords: human papillomavirus DNA, colorectal cancer, polymerase chain reaction.

Papillomaviruses are responsible for a wide variety of papillomatous proliferations in animals and humans. ${ }^{1}$ They seem to interact synergistically with chemical and physical carcinogens, and thus resemble tumour promotors in function. ${ }^{2}$ The finding that specific types of HPVs are frequently associated with specific types of human tumour has been reported in the past few years. ${ }^{3}$ It has been suggested that condyloma (genital warts) and mild forms of dysplasia usually contain HPV 6 or 11.45 HPV 16 and 18, however, are consistently associated with severe dysplasia, carcinoma in situ, and invasive carcinoma. ${ }^{6-8}$ Most external anogenital neoplasias and cervical carcinomas are associated with HPV 16, and more rarely with HPV 18 or HPV $33 .{ }^{910}$ Based on these studies, HPV may play an important part in inducing specific types of human cancer. Although HPVs have a close correlation with cervical carcinoma, they have also been found in adenocarcinomas in a few reports. ${ }^{11} 12$ We have detected HPVs in colon cancer cell lines ${ }^{13}$ and have shown that HPV may be implicated in colorectal carcinogenesis. ${ }^{14}$ The expression of different HPVs in clinical specimens of colorectal tumours, however, has never been studied fully.
Polymerase chain reaction (PCR) is the only diagnostic method sensitive enough to detect latent HPV infections. ${ }^{15}$ One copy of HPV DNA in $10^{5}$ cells $^{16}$ or 20 viral copies in cervical cancer biopsy tissue ${ }^{17}$ can be detected by PCR. PCR can be used currently to amplify DNA in paraffin embedded sections. ${ }^{18} \mathrm{We}$ describe the expressions of HPV types $6,11,16,18$, and 33, detected by PCR and Southern blot hybridisation and substantiate their possible role in colorectal tumours.

\section{Methods}

CLINICAL SPECIMENS AND CELL LINES

Paraffin embedded specimens of 37 adenomas and 70 carcinomas were collected for this study. All clinicopathological data including sex, age, histological differentiation, tumour stage, tumour location, and survival years were recorded. The five year survival status of all patients was also collected. The cases of colorectal cancers were classified by Astler and Coller's classification ${ }^{19}$ : eight cases were stage $A$, 24 stage $B(B 1+B 2), 35$ stage $C(C 1+C 2)$, and 11 cases stage $D$. A cell line containing HPV 16, CaSki, and another containing HPV $18, \mathrm{HeLa}$, were used as positive controls. The DNA of 10 normal colonic epithelia was used as a negative control.

\section{DNA EXTRACTION}

Five sections $(5 \mu \mathrm{m})$ were cut from each paraffin block and placed in a $500 \mu l$ Eppendorf tube. One section was stained with haematoxylin and eosin for histological observation. The sections were deparaffinised by adding $200 \mu \mathrm{l}$ of xylene, they were vortexed, and were then pelleted by centrifugation. Xylene was decanted, and its residue was removed with $200 \mu \mathrm{l}$ of $99.5 \%$ ethanol. The specimens were then centrifuged and decanted again. After desiccation, $10 \mathrm{mM}$ Tris buffer solution, $\mathrm{pH}$ $7 \cdot 5$, was added to each sample. The sections were digested at $37^{\circ} \mathrm{C}$ overnight with proteinase K (Sigma, St Louis, MI, USA) at 100 $\mu \mathrm{g} / \mathrm{ml}$ in extraction buffer $\left(10^{-2} \mathrm{M}\right.$ Tris- $\mathrm{HCl}$, $\mathrm{pH} 7 \cdot 5,1 \mathrm{mM}$ EDTA, $\mathrm{pH} 7 \cdot 9$, sodium dodecyl sulphate (SDS) $0.5 \%$ ). The tube was then heated at $100^{\circ} \mathrm{C}$ for 10 minutes to inactivate the proteinase $\mathrm{K}$. All the procedures were performed carefully to avoid contamination.

PCR

The E6-E7 region of the HPV genome was 
TABLE I Primers and probes for DNA amplification of human papillomavirus (HPV) polymerase chain reaction

\begin{tabular}{|c|c|c|}
\hline$H P V$ & Nucleotide sequences & Product size (bp) \\
\hline \multicolumn{3}{|l|}{ Primers: } \\
\hline HPV 6/11 & $\begin{array}{l}\text { 5'-TACACTGCTGGACAACATGC-3' } \\
\text { 3'-CACACAGGGTAGACGCGTG-5' }\end{array}$ & 301 \\
\hline HPV 16 & 5'-CCCAGCTGTAATCATGCATGGAGA-3' & \\
\hline & 3'-ACCTTCTGGACAATTACCCGTGTG-5' & 253 \\
\hline HPV 18 & 5'-CGACAGGAACGACTCCAACGA-3' & \\
\hline & 3'-TCAATTTAGTAGTTGTAAATGGTCG-5' & 201 \\
\hline HPV 33 & 5'-GCAGTAAGGTACTGCACGACTATG-3' & \\
\hline & 3'-TGCTAAAGTATTATAAAGCCCAGC-5' & 413 \\
\hline $\begin{array}{l}\text { Probes: } \\
\text { HPV } 6 \\
\text { HPV } 11 \\
\text { HPV } 16 \\
\text { HPV } 18 \\
\text { HPV } 33\end{array}$ & $\begin{array}{l}\text { 5'-CAGTGTACAGAAACA-3' } \\
\text { 5'-CAACTACAAGACCTTTTGC-3' } \\
\text { 5'-CCGGACAGAGCCCATTAC-3' } \\
\text { 5'-TAAGGCAACATTGCAAGACA-3' } \\
\text { 5'-CACAACATTGAACTACAGTGCGTGGAA }\end{array}$ & АAACCTT-3' \\
\hline
\end{tabular}

chosen to prepare the primers. ${ }^{20}$ The sequences of the primers and probes and the amplified length of the HPV viral genome are listed in Table I.

PCR was performed with the Gene Ampli Taq kit (Perkin Elmer-Cetus, Emeryville, CA, USA) by the modified method of Kogan et al. ${ }^{21}$ Samples were then denatured for 10 minutes at $94^{\circ} \mathrm{C}$ and subjected to 35 cycles of amplification. A cycle represents primer annealing for 2 minutes at $55^{\circ} \mathrm{C}$, primer extension for 1.5 minutes at $72^{\circ} \mathrm{C}$, and denaturation for 1 minute at $94^{\circ} \mathrm{C}$. Amplified DNA $(10 \mu \mathrm{l})$ was electrophoresed on 3\% NuSieve agarose gel (FMC Corp, Rockland, ME, USA) and made visible by ultraviolet light after staining with ethidium bromide.

SOUTHERN BLOT HYBRIDISATION

After staining with ethidium bromide, the DNA was denatured in situ with $\mathrm{NaOH}$ and transferred to nitrocellulose filter paper by Southern's method. ${ }^{22}$ The filters were hybridised with ${ }^{32} \mathrm{P}-5^{\prime}$ end-labelled oligonucleotide probes under high stringency conditions, as in previous reports. ${ }^{13} 14$ After hybridisation, the filter was washed under low stringency condition at room temperature and finally exposed to an $x$ ray film (Eastman Kodak, Rochester, NY, USA) by an autoradiographic method at $-70^{\circ} \mathrm{C}$.

\section{STATISTICS}

The difference in cancer differentiation, staging, and location between HPV positive and negative cases were analysed by one-way

TABLE II Typing of human papillomavirus (HPV) DNA in the different stages of carcinomas as determined by polymerase chain reaction and Southern blot hybridisation

\begin{tabular}{|c|c|c|c|c|c|}
\hline & \multicolumn{5}{|c|}{$H P V$} \\
\hline & $6 / 11$ & 16 & 18 & 33 & Positive (\%) \\
\hline $\begin{array}{l}\text { Normal mucosa } \\
\text { Carcinoma: }\end{array}$ & 0 & 0 & 0 & 0 & $0 / 10(0)$ \\
\hline $\begin{array}{c}\text { Stage } A(n=8) \\
\text { B1 }(n=8) \\
\text { B2 }(n=16) \\
\text { C1 }(n=9) \\
\text { C2 }(n=18) \\
D(n=22)\end{array}$ & $\begin{array}{l}0 \\
1 \\
2 \\
1 \\
1 \\
1\end{array}$ & $\begin{array}{l}2 \\
2 \\
5 \\
3 \\
9 \\
5\end{array}$ & $\begin{array}{l}2 \\
1 \\
2 \\
1 \\
3 \\
2\end{array}$ & $\begin{array}{l}0 \\
0 \\
0 \\
0 \\
0 \\
0\end{array}$ & $\begin{array}{l}4 / 8(50) \\
3 / 8(37 \cdot 5) \\
9 / 16(56 \cdot 3) \\
4 / 9(44 \cdot 4) \\
10 / 18(55 \cdot 6) \\
7 / 11(63 \cdot 6)\end{array}$ \\
\hline Total & 6 & 26 & 11 & 0 & $37 / 70(52.9) \dagger$ \\
\hline
\end{tabular}

${ }^{\star}$ Control group. $†$ The ratio of HPV positive cases in carcinomas. analysis of variance (ANOVA) test. The differences in HPVs between adenomas and carcinomas were analysed by the Student's $t$ test. This test was also used to analyse the differences between HPVs in respect of patient's sex, age, and five year survival rate.

\section{Results}

About $30 \%$ (11 of 37 ) of the DNA extracted from adenomas contained DNA sequences related to HPV $6,11,16$, or 18 . HPVs DNA were found in $52.9 \%$ (37 of 70 ) of 70 carcinomas. The overall incidence of infection by specific HPV types is given in Table II. The difference in HPV infection between adenomas and carcinomas was significant $(p<0 \cdot 05)$. HPV 16 was the most common HPV found to infect colorectal carcinomas. In addition, there was a significant difference in HPV 16 expression in HPV positive cases of adenoma and carcinoma ( 4 of $11 v 26$ of 37) $(p<0.05)$. In the control group, there was no normal mucosa that contained HPV DNA. The Southern blot analysis of HPV infection in colorectal carcinoma is shown in Figure 1. Double infections were found in one of stage $\mathrm{B} 1$, one of stage $\mathrm{C} 1$, three stage $\mathrm{C} 2$, and one of stage D carcinomas respectively. Thus, the numbers of specimens positive for each specific HPV type were total more tha

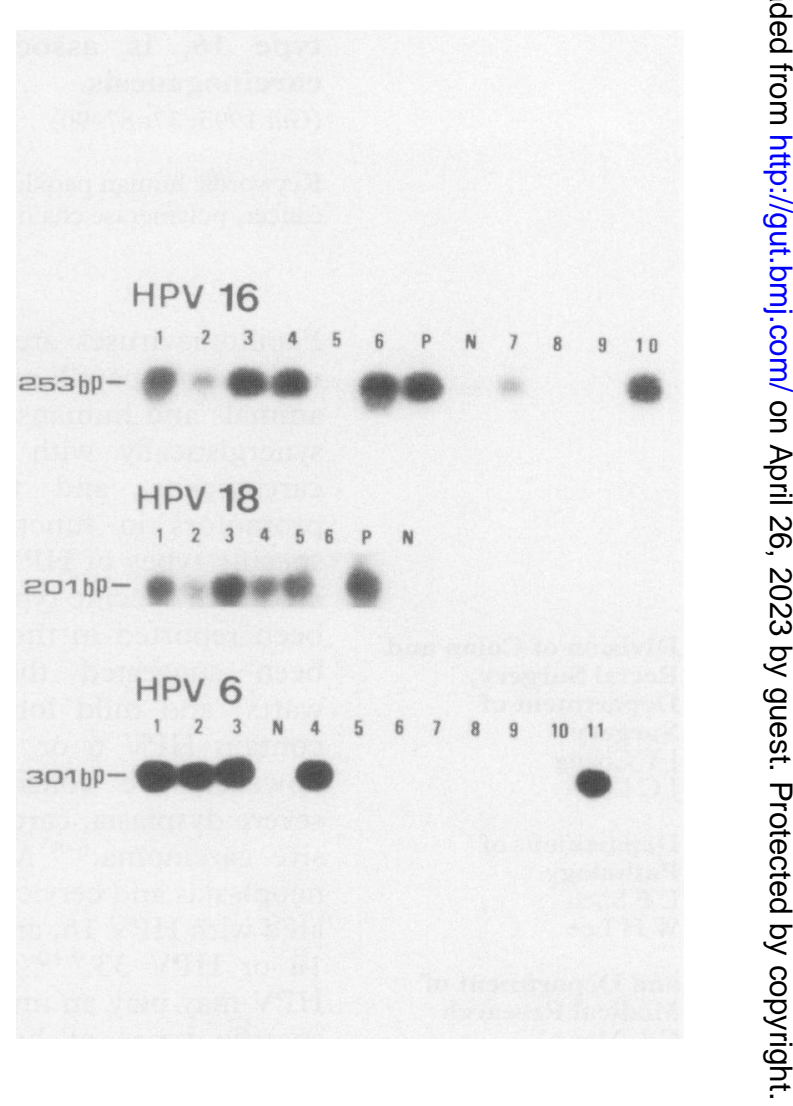

Genomic DNA of colorectal cancers detected by polymerase chain reaction with human papillomavirus (HPV) primer and Southern blot hybridisation. Upper section HPV 16: lanes 1-4, 6, 7, and 10 were positive and lanes 5, 8, and 9 were negative. $P=C a S k i$ cell line (positive control) and $N=$ negative control. Middle section HPV 18: lanes 1-5 were positive and lane 6 was negative. $P=H$ He L cell line (positive control). Lower section HPV 6: lanes 1-4 and 11 were positive and lanes 5-10 were negative. 
TABLE III Incidence of human papillomaviruses (HPV) in a differentiated series of carcinomas

\begin{tabular}{lllll}
\hline \multirow{2}{*}{$\begin{array}{l}\text { HPV } \\
\text { type }\end{array}$} & \multicolumn{4}{l}{ Differentiation } \\
\cline { 2 - 5 } & Well & Moderate & Poor & Mucinous \\
\hline $6 / 11$ & 1 & 4 & 1 & \\
16 & 2 & 17 & 5 & 2 \\
18 & 1 & 8 & 2 & \\
Total & $4 / 10$ & $25 / 45$ & $6 / 12$ & $2 / 3$ \\
& $(40 \%)$ & $(55 \cdot 6 \%)$ & $(50 \%)$ & $(66 \cdot 7 \%)$ \\
\hline
\end{tabular}

HPV type were total more tha

$\mathrm{n}$ the number of positive cases in Table II.

There was no significant association between HPV positivity and the cell differentiation of carcinomas $(p>0.05)$ as is shown in Table III. Double infections were found in four cases of moderate and two cases of poor differentiation. The five year survival rate was $37 \%$ (10 of 27 ) in HPV positive cases and $42.4 \%$ (14 of 19) in negative cases. There was no significant association between HPV and survival in patients with colorectal cancer. In addition, there was no distinct difference in the mean age, sex or tumour location between HPV positive and negative cases.

\section{Discussion}

Although HPV DNA certainly prevails in the genital tract, ${ }^{6-8}$ it may also be a risk factor for neoplasm in other locations such as the lung, ${ }^{23}$ oral cavity, ${ }^{24}$ larynx,${ }^{25}$ skin, ${ }^{26}$ and tongue. ${ }^{5}$ The association between HPV and colorectal neoplasia has been described in a few studies. ${ }^{12}{ }^{21}$ In our previous studies, we found HPV 16 and HPV 18 DNA sequences in the DNA of colorectal cancer cells. ${ }^{13}$ Furthermore, HPV 16 DNA in colon cells could be transfected during the process of malignant transformation..$^{14}$ Since Yasumoto ${ }^{27}$ proved that HPV 16 DNA was closely associated with malignant transformation, HPV 16 DNA has been reported to activate proto-oncogene and play an important part in carcinogenesis. ${ }^{28}$ These results suggest that HPV might play a causal part in colorectal carcinogenesis.

Based on HPV prevalence rates in cervical carcinomas and in vitro transforming capabilities, HPV 16 and 18 genotypes have been grouped as high risk, and HPV 6 and 11 as low risk for the development of cervical cancers. ${ }^{12}$ HPV 6 and 11 have been detected almost exclusively in benign lesions such as laryngeal papillomas, benign condyloma acuminata and low grade cervical intraepithelial neoplasia (CIN). ${ }^{12}$

With regard to the occurrence of specific HPV types in cervical tumours, HPV 16 was the most prevalent in invasive carcinomas. ${ }^{67}$ HPV 16 DNA is therefore the predominant genotype to induce cancer. This DNA may integrate into the host genome near the $c-m y c$ oncogen $e^{28} 29$ and activate $c-m y c$ expression. ${ }^{13}$ In our study, $70 \%$ (26 of 37) of HPV DNA positive cases contained HPV 16 DNA. This result suggested that HPV 16 may also have a role in the several stages of colorectal carcinogenesis.

The expressions of HPV DNA in adenomas and carcinomas were significantly different in our study $(\mathrm{p}<0 \cdot 05)$. In addition, we have also found increased association of HPV with progressive dysplasia in adenomas (unpublished data). Our results were consistent with clinicopathological evidence in previous reports ${ }^{30-32}$ and suggested that most colorectal carcinomas arise from pre-existing adenomas (adenomacarcinoma sequence). However, there was no correlation between the existence of HPV and differentiation of carcinomas $(p>0.05)$. This finding indicated an important biological difference between adenomas and carcinomas.

We also analysed the associations between HPV and sex, age, tumour stage, tumour location, and survival status. There was no close correlation with any of these factors. The results suggested that viral infections were not retrograde transmission from anus to caecum. Furthermore, HPV DNA may play a crucial part in promoting colorectal carcinogenesis, but not in cancer invasion and metastasis.

$\mathrm{We}^{1314}$ and Kirgan et al ${ }^{33-36}$ have shown HPV DNA in colonic tumours, whereas Palmer $e^{a l^{37}}$ and Shroyer $e a^{38}$ did not. This discrepancy may result from different techniques or samples. In the study of Shroyer et al for example almost half of the metastatic samples were used. Although the association between HPV and colonic tumours is not confirmed by everyone and more cases will be needed to substantiate it fully, our data suggest that HPV DNA is associated with the development of colorectal carcinoma.

We thank Mr F G Lin and Ms S I Tsai for technical assistance and Ms Jean Chuang for reading the manuscript.

Supported by the grant NSC 82-0412-B016-076 from the National Science Council, Taiwan, ROC.

1 zur Hausen H. Papillomavirus in human cancer. Cancer 1987; 59: 1692-6.

2 zur Hausen $\mathrm{H}$. Human genital cancer: Synergism between two virus infections or synergism between a virus infection and initiating events. Lancet 1982; ii: 1370-2.

3 Gissmann L, Wolnik H, Ikenberg H, Koldovsky U, Schnurch HG, zur Hausen $H$. Human papillomavirus type 6 and 11 sequences in genital and laryngeal papillomas and in some cervical cancer biopsies. Proc Natl Acad Sci USA 1983; 80: 560-3.

4 Gissman L. Papillomaviruses and their association with cancer in animals and in man. Cancer Surv 1984; 3: 161-81.

5 de Villiers EM, Weidauer $\mathrm{H}$, Otto $\mathrm{H}$, zur Hausen $\mathrm{H}$. Papillomavirus DNA in human tongue carcinoma. Int $\mathcal{F}$ Cancer 1986; 36: 575-8.

6 McCane DJ. Prevalence of human papillomavirus type 16 DNA sequence cervical intraepithelial neoplasia and invasive carcinoma of the cervix. Br $\mathcal{f}$ Obstet Gynaecol 1986; 92: 1101-5.

7 Durst M, Gissmann L, Ikenberg H, zur Hausen H. A papillomavirus DNA from a cervical carcinoma and its prevalence in cancer biopsy samples from different geographic regions. Proc Natl Acad Sci USA 1983; 80: 3812-5.

8 Boshart M, Gissmann L, Ikenberg H, Kleinheinz A Scheurlen W, zur Hausen H. A new type of papillo-
Schart Scheurlen W, zur Hausen $H$. A new type of papillo-
mavirus DNA, its presence in genital cancer biopsies and mavirus DNA, its presence in genital cancer biopsies and
in cell lines derived from cervical cancer. $E M B O \mathcal{F} 1984$; 3: 1151-7.

9 Crum CP, Liskow A, Petras P, Kong WC, Frick HC. Vulvar intraepithelial neoplasia (severe atypia and carcinoma in situ). A clinicopathologic analysis of 41 cases. Cancer 1984; 54: 1429-34.

10 Beaudenon $S$, Kremsdrof D, Croissant $O$, Jablonska $S$, Wain-Hobson S, Orth G. A novel type of human papillomaviruses associated with genital neoplasia. Nature 1986; 321: 246-9.

11 Tase T, Okagaki T, Clark BA. Human papillomavirus types and localization in adenocarcinoma and adenosquamous carcinoma of the uterine cervix: A study by in situ DNA carcinoma of the uterine cervix: A study by
hybridization. Cancer Res 1988; 48: 993-8.

12 Ostrow RS, Manias DA, Fong WJ, Zachow KR, Faras AJ. A survey of human cancer for human papillomavirus DNA by filter hybridization. Cancer 1987; 59: 429-34.

13 Cheng JY, Meng CL, Chao CF, Gau SD, Lin JC. Human papillomavirus type-related DNA and c-myc oncogene alterations in colon cancer cell lines. Dis Colon Rectum 1991; 34: 469-74. 
14 Cheng JY, Meng CL, Chao CF, Gau SD, Lin JC. Human papillomavirus 16 DNA in NIH3T3 cells transformed by colon cancer cellular DNA. Gut 1993; 34: 1710-3.

15 Syrjänen S, Saastamoinen J, Chang F, Ji H, Syrjanen K. Colposcopy, punch biopsy, in situ DNA hybridization, and the polymerase chain reaction in searching for genital and the polymerase chain reaction in searching for genital human papillomavirus (HPV) infections in women

16 Saiki RK, Scharf S, Faloona F, Mullis KB, Horn GT, Erlich $\mathrm{HA}$, et al. Enzymatic amplification of $\beta$-globin genomic $\mathrm{HA}$, et al. Enzymatic amplification of $\beta$-globin genomic sequences and restriction site analysis for
sickle cell anemia. Science 1985; 230: 1350-3.

17 Shibata DK, Arnheim N, Martin WJ. Detection of human papillomavirus in paraffin-embedded tissue using the polymerase chain reaction. $\mathcal{F} \operatorname{Exp} M e d 1988 ; 167: 225-30$.

18 Shibata DK, Fu YS, Gupta JW, Shan KV, Arnheim N, Martin WJ. Detection of human papillomavirus in normal and dysplastic tissue by the polymerase chain reaction. Lab Invest 1988; 59: 555-9.

19 Astler VB, Coller FA. The significant prognosis of direct extension of carcinoma of the colon and rectum. Ann Surg 1954; 139: 846-51.

20 Schwarz E, Fresse UK, Gissmann L, Mayer W, Roggenbuck B, Stremlau A, et al. Structure and tranRoggenbuck B, Stremlau A, et al. Structure and tran-
scription of human papillomavirus sequences in cervical scription of human papillomavirus sequen
carcinoma cells. Nature 1985; 314: 111-4.

21 Kogan SC, Doherty M, Gitschier J. Improved method for prenatal diagnosis of genetic diseases by analysis of amplified DNA sequences. $N$ Engl $\mathcal{F}$ Med 1987; 317: 985-90.

22 Southern EM. Detection of specific sequences among DNA fragments separated by gel electrophoresis. $\mathcal{f}$ Mol Biol 1975; 98: 503-17.

23 Bejui-thivolet F, Liagre N, Chignol MC, Chardonnet Y, Patricot LM. Detection of human papillomavirus DNA in squamous bronchial metaplasia and squamous cell carcinomas of the lung by in situ hybridization using biotinated probes in paraffin-embedded specimens. Human Pathol 1990; 21: 111-6.

24 Loning T, Ikengberg H, Becker J, Gissmann L, Hoepfner I, zur Hausen $\mathrm{H}$. Analysis of oral papillomas, leukoplakias and invasive carcinomas for human papillomavirus typerelated DNA. F Invest Dermatol 1985; 84: 417-20.

25 Brandsma JL, Steinberg BM, Abramson AL, Winkler B. Presence of human papillomavirus type 16 related sequence in verrucous carcinoma of the larynx. Cancer Res 1986; 46: 2185-8.

26 Lutzner MA, Orth G, Dutronquay V. Detection of human papillomavirus type 5 DNA in skin cancers of an immunosuppressed renal allograft recipient. Lancet 1983; ii: 422-4.

27 Yasumoto S, Burkhardt AL, Dominger J, Dipaolo JA. Human papillomavirus type 16 DNA-induced malignant Human papilomavirus type 16 DNA-induced malignant

28 Dürst M, Croce CM, Gissmann L, Schwarz E, Huebner K. Papillomavirus sequences integrate near cellular oncoPapillomavirus sequences integrate near cellular oncogenes in some cervical

29 Broker T, Thomas R. Structure and genetic expression of papillomaviruses. Obstet Gynecol Clin North Am 1987; 14: 329-48.

30 Morson BC, Bussey HJR. Magnitude of risk for cancer in patients with colorectal adenomas. Br $\mathcal{F}$ Surg 1985; 72 (suppl): 23-8

31 Goh HS, Jass JR. DNA content and adenoma-carcinoma sequence in the colorectum. $f$ Clin Pathol 1986; 39: 387-92.

32 Kaklamanis L, Gatter KC, Mortensen N, Baigrie RJ, Heryet A, Lane DP, Harris AL. p53 expression in coloHeryet A, Lane DP, Harris AL. p53 expression in

33 Kirgan D, Manalo P, McGregor B. Immunohistochemical demonstration of human papilloma virus antigen in human colon neoplasms. F Surg Res 1990; 48: 397-402.

34 Kirgan D, Manalo P, Hall M, McGregor B. Association of human papillomavirus and colon neoplasms. Arch Surg 1990; 125: 862-5.

35 Manalo P, Highison G, McGregor B, Hall M. Electron microscopic evidence of papillomavirus in human colon neoplasms. Am f Clin Pathol 1991; 96: 413.

36 McGregor B, Byrne P, Kirgan D, Albright J, Manalo P, Hall $M$. Confirmation of the association of human papillomavirus with human colon cancer. Am F Surg 1993; 166: 738-42.

37 Palmer JG, Scholefield JH, Coates PJ, Shepherd NA, Jass $J R$, Crawford LV, et al. Anal cancer and human papillomaviruses. Dis Colon Rectum 1989; 32: 1016-22.

38 Shroyer K, Kim J, Manos M, Greer C, Pearlman N, Franklin W. Papillomavirus found in anorectal squamous carcinoma, not in colon adenocarcinoma. Arch Surg 1992; 127: 741-4. 